\title{
Prosthecobacter fluviatilis sp. nov., which lacks the bacterial tubulin btubA and btubB genes
}

Correspondence Minoru Takeda mtake@ynu.ac.jp

\author{
Minoru Takeda, ${ }^{1}$ Akiko Yoneya, ${ }^{1}$ Yuichi Miyazaki, ${ }^{1}$ Keiko Kondo, ${ }^{1}$ \\ Hiroko Makita, ${ }^{1}$ Masashi Kondoh, ${ }^{2}$ Ichiro Suzuki ${ }^{1}$ and Jun-ichi Koizumi ${ }^{1}$ \\ ${ }^{1}$ Division of Materials Science and Chemical Engineering, Faculty of Engineering, Yokohama \\ National University, 79-5 Tokiwadai, Hodogaya, Yokohama 240-8501, Japan \\ ${ }^{2}$ Instrumental Analysis Center, Yokohama National University, 79-5 Tokiwadai, Hodogaya, \\ Yokohama 240-8501, Japan
}

\begin{abstract}
Leptothrix cholodnii is a sheathed bacterium often found in metal-rich and oligotrophic aquatic environments. A bacterial strain that is able to degrade the $\mathrm{NaOH}$-treated sheath of $L$. cholodnii was isolated. The isolate was a Gram-negative, aerobic and prosthecate bacterium. The optimum growth temperature and $\mathrm{pH}$ were $30{ }^{\circ} \mathrm{C}$ and $\mathrm{pH} 7.0$, respectively. The DNA G $+\mathrm{C}$ content was $62.9 \mathrm{~mol} \%$. The major respiratory quinone was MK-6. A phylogenetic analysis based on the $16 \mathrm{~S}$ rRNA gene indicated that the isolate is a member of the genus Prosthecobacter. The nearest relative was the type strain of Prosthecobacter vanneervenii, with a similarity of $97.1 \%$. However, the isolate does not possess the bacterial tubulin genes, btubA and btubB, unique to known species of the genus Prosthecobacter. It is proposed that the isolate represents a novel species, Prosthecobacter fluviatilis sp. nov. The type strain is $\mathrm{HAQ}-1^{\top}\left(=\mathrm{JCM} 14805^{\top}=\mathrm{KACC} 12649^{\top}=\mathrm{KCTC} 22182^{\top}\right)$.
\end{abstract}

Members of the Sphaerotilus-Leptothrix group are aquatic filamentous bacteria that are able to oxidize metal ions (Eikelboom, 1975; van Veen et al., 1978) and play a role in biomineralization (Ghiorse \& Ehrlich, 1992). Their filamentous growth is accomplished by the formation of a sheath, a tube-like extracellular structure in which cells are enclosed, forming a filament. Insoluble metal oxides generated by this group of bacteria are not accumulated directly on the cell surface, but are deposited on the sheath (van Veen et al., 1978), possibly allowing steady cell division. The sheaths of the Sphaerotilus-Leptothrix group are formed by association of mucopolysaccharide modified with a cysteine-rich peptide and probably comprise a novel category of structural glycoconjugates (Emerson \& Ghiorse, 1993; Makita et al., 2006; Takeda et al., 1998, 2003, 2005). To investigate the chemical structure of a complicated structural macromolecule, an enzyme is desired that degrades the macromolecule specifically, such as lysozyme for peptidoglycans. A degrading enzyme specific for the sheath of Sphaerotilus natans is already available from Paenibacillus koleovorans (Takeda et al., 2002, 2003). In contrast, no microbe that degrades the sheath of Leptothrix cholodnii has so far been isolated.

The GenBank/EMBL/DDBJ accession number for the $16 \mathrm{~S}$ rRNA gene sequence of strain $\mathrm{HAQ}-1^{\top}$ is $\mathrm{AB} 305640$.

A graph showing growth of strain $\mathrm{HAQ}-1^{\top}$ on mucopolysaccharide and figures showing the positions of PCR primers specific for the btubA and btub $B$ genes are available as supplementary material with the online version of this paper.
Therefore, we attempted to isolate microbes from soil and river water capable of growth on the sheath of $L$. cholodnii. Although we could not find any microbes with this desirable property, a bacterial strain that can utilize the polysaccharide prepared from the sheath was obtained. Based on a taxonomic characterization, the isolate was found to be a novel strain related to Prosthecobacter vanneervenii. Interestingly, two bacterial tubulin genes (btubA and $b t u b B$ ) unique to the genus Prosthecobacter were not detected in the isolate.

The sheath of $L$. cholodnii ATCC $51168^{\mathrm{T}}$ was obtained by a previously described method (Takeda et al., 2005) and used to prepare a screening medium of the following composition ( $1^{-1}$ distilled water): $0.25 \mathrm{~g}$ sheath material, $0.2 \mathrm{~g}$ $\left(\mathrm{NH}_{4}\right)_{2} \mathrm{SO}_{4}, \quad 0.3 \mathrm{~g} \quad \mathrm{NaNO}_{3}, \quad 0.2 \mathrm{~g} \quad \mathrm{CaCl}_{2}, \quad 0.06 \mathrm{~g}$ $\mathrm{MgSO}_{4} \cdot 7 \mathrm{H}_{2} \mathrm{O}, 0.1 \mathrm{~g} \quad \mathrm{KH}_{2} \mathrm{PO}_{4}, 0.15 \mathrm{~g} \quad \mathrm{Na}_{2} \mathrm{HPO}_{4} \cdot 2 \mathrm{H}_{2} \mathrm{O}$ and $2.8 \mathrm{mg} \mathrm{FeSO}_{4} \cdot 7 \mathrm{H}_{2} \mathrm{O}$. Screening was carried out aerobically at $25{ }^{\circ} \mathrm{C}$, but no sheath-degrading microbes were detected. We then tried to find microbes capable of growing on $\mathrm{N}$-acetylated mucopolysaccharide that was prepared from the sheath by the method described below. Sheath material $(50 \mathrm{mg}$ ) was soaked in $50 \mathrm{ml} 3 \mathrm{M} \mathrm{NaOH}$ follow by incubation at $30{ }^{\circ} \mathrm{C}$ for $72 \mathrm{~h}$ to remove the peptide moiety and to release the mucopolysaccharide. The solution was neutralized with phosphoric acid, passed through a glass filter and dialysed against a $0.1 \mathrm{M} \mathrm{NaHCO}_{3}$ solution. To the dialysate, a saturating amount of $\mathrm{NaHCO}_{3}$ was added and then acetic anhydride was slowly added until the $\mathrm{pH}$ of the solution reached about 6 . The solution 
was passed through a column $(2.5 \times 22 \mathrm{~cm})$ packed with AG50W-X8 resin $\left(\mathrm{H}^{+}\right.$form; Bio-Rad) and the eluate was dialysed against distilled water. The dialysate was finally lyophilized to recover the $\mathrm{N}$-acetylated mucopolysaccharide $(25-30 \mathrm{mg})$. The composition of the modified screening medium for isolation of microbes that utilize the $\mathrm{N}$-acetylated mucopolysaccharide was the same as that of the original screening medium described above except that the sheath material was replaced with the $\mathrm{N}$-acetylated mucopolysaccharide. A culture supplemented with river water collected from the Yamada River (Munakata, Fukuoka, Japan) became turbid at $25{ }^{\circ} \mathrm{C}$ within 2 months. After subculturing three times with the modified screening medium, colony isolation was carried out with plates of the same medium ( $1.5 \%$ agar $)$ at $25{ }^{\circ} \mathrm{C}$. Each colony formed on the plates was transferred to liquid medium and incubated at $25{ }^{\circ} \mathrm{C}$. One of the cultures became turbid within 1 month and the isolate was designated strain HAQ$1^{\mathrm{T}}$. More rapid growth was observed, and degradation of the $\mathrm{N}$-acetylated mucopolysaccharide was confirmed, in a medium supplemented with soytone peptone as the nitrogen source (Supplementary Fig. S1, available in IJSEM Online). However, strain HAQ- ${ }^{\mathrm{T}}$ could not grow on the original screening medium.

When strain $\mathrm{HAQ}-1^{\mathrm{T}}$ was cultured aerobically in a complex medium (MMB medium; Staley \& Mandel, 1973) at $30{ }^{\circ} \mathrm{C}$ for 3 days, straight, fusiform cells with prosthecae at one pole were observed (Fig. 1a). Cell division occurred at the non-prosthecate pole (Fig. 1a). Cells were $0.3-0.7 \mu \mathrm{m}$ wide and $1.8-8 \mu \mathrm{m}$ long (Fig. 1). The cells lacked flagella and were non-motile. Spores were not formed. These features are typical for the genus Prosthecobacter (Staley et al., 1976). Cells of strain HAQ- ${ }^{\mathrm{T}}$ tended to attach to each other and to form cell clumps (Fig. 1b), different from known Prosthecobacter strains (Staley et al., 1976). It is likely that the expanded fibrous material becomes interlaced to bind the adjoining cells (Fig. 1a). Gram-staining was negative using Favour-G reagents (Nussui Pharmaceutical). Anaerobic growth in MMB medium at $30{ }^{\circ} \mathrm{C}$ was tested using a BBL GasPack pouch (Becton Dickinson), and no growth was observed within 2 months. Colonies formed on solidified MMB medium were pale yellow, convex and opaque.

For determination of the effect of $\mathrm{pH}$ on growth, the bacterium was cultured statically in $\mathrm{MMB}$ medium at various pHs (by addition of $\mathrm{HCl}$ or $\mathrm{NaOH}$ ) at $30{ }^{\circ} \mathrm{C}$ for 4 days, and the optical density at $660 \mathrm{~nm}$ was then measured. Growth of strain HAQ- $1^{\mathrm{T}}$ occurred at $\mathrm{pH}$ 4.58.1, with an optimum at $\mathrm{pH}$ 6.5-7.0. The effect of temperature was tested by static cultivation for 1 month in $\mathrm{MMB}$ medium at various temperatures. Growth was assessed by an increase in the optical density at 1-3 day intervals. The growth temperature range of strain HAQ- $1^{\mathrm{T}}$ was $10-38{ }^{\circ} \mathrm{C}$ with an optimum at $30{ }^{\circ} \mathrm{C}$. The doubling time at $30{ }^{\circ} \mathrm{C}$ was estimated to be $4.6 \mathrm{~h}$ by measuring the optical density at intervals of $4 \mathrm{~h}$ during shaking cultivation in MMB medium. These phenotypic properties
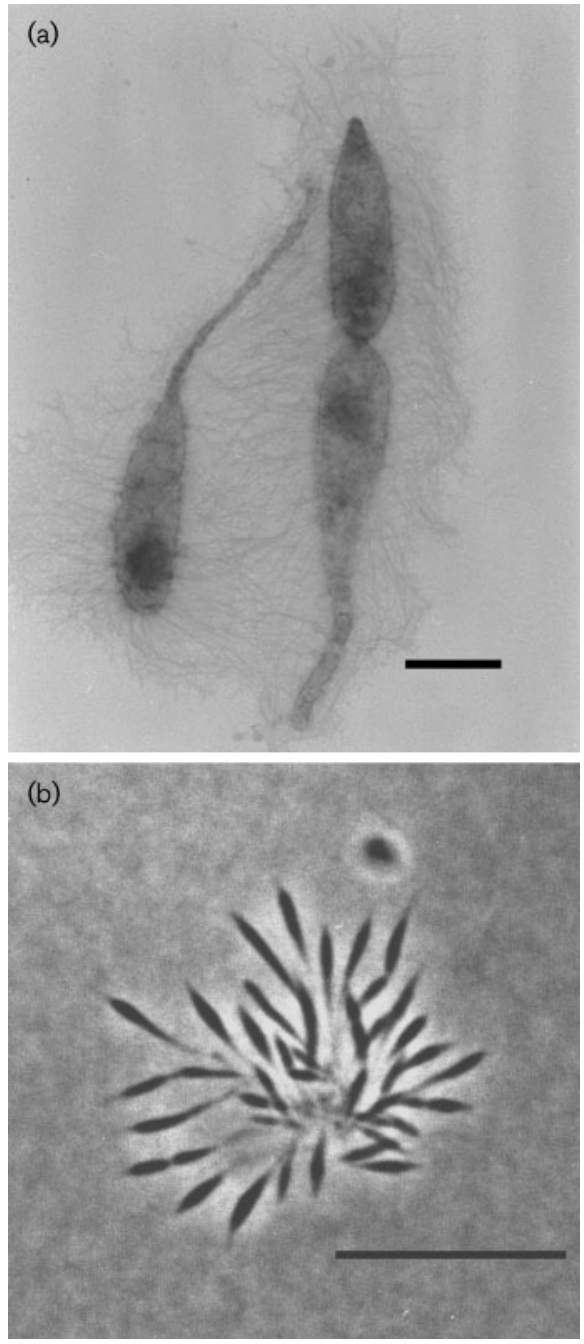

Fig. 1. Negatively stained electron micrograph (top; bar, $1 \mu \mathrm{m}$ ) and phase-contrast micrograph (bottom; bar $10 \mu \mathrm{m}$ ) of strain $\mathrm{HAQ}-1^{\top}$. Strain $\mathrm{HAQ}-1^{\top}$ was cultured statically in MMB medium for 2 days and then subjected to electron microscopy (JEM-2000 FX II; JEOL) and phase-contrast microscopy (Axioskop; Zeiss).

are similar to those of other members of the genus Prosthecobacter. Cells grown on MMB agar plates at $30{ }^{\circ} \mathrm{C}$ for 3 days formed a few bubbles in $3 \%(\mathrm{v} / \mathrm{v}) \mathrm{H}_{2} \mathrm{O}_{2}$ solution, thus exhibiting a weak catalase activity. Oxidase activity was positive, because the cells oxidized $p$ phenylenediamine. The capacity to utilize various sugars was tested using defined DM medium (van Ert \& Staley, 1971) as a basal medium according to the method of Staley et al. (1976). Utilization was judged by an increase in the turbidity of the cultures, with results given in the species description and in Table 1. The carbohydrate utilization pattern of strain HAQ- $1^{\mathrm{T}}$ is useful in differentiating it from type strains of the genus Prosthecobacter.

Total DNA of strain HAQ- $1^{\mathrm{T}}$ grown on MMB medium was prepared using a Genomic-Prep blood DNA isolation kit 
Table 1. Carbohydrate utilization of strain $\mathrm{HAQ}-1^{\top}$ and type strains of Prosthecobacter species

Strains: 1 , P. dejongeii $\mathrm{FC}^{\mathrm{T}} ; 2$ P. vanneervenii $\mathrm{FC}^{\mathrm{T}} ; 3, P$. debontii $\mathrm{FC}^{\mathrm{T}}$; 4, P. fusiformis $\mathrm{FC} 4^{\mathrm{T}} ; 5$, strain HAQ- ${ }^{\mathrm{T}}$. Reference data are from Hedlund et al. (1997). All strains were positive for utilization of D-glucose, D-galactose, D-mannose, D-xylose, sucrose, maltose and cellobiose.

\begin{tabular}{|c|c|c|c|c|c|}
\hline Carbohydrate & 1 & 2 & 3 & 4 & 5 \\
\hline L-Rhamnose & + & + & + & + & - \\
\hline Trehalose & + & + & + & + & - \\
\hline D-Ribose & + & + & + & - & + \\
\hline L-Arabinose & - & - & + & + & - \\
\hline D-Fructose & - & + & + & - & - \\
\hline Raffinose & - & + & - & - & - \\
\hline Glycogen & + & + & - & - & - \\
\hline D-Glucosamine & - & + & - & - & - \\
\hline$N$-Acetyl-D-glucosamine & + & + & + & - & + \\
\hline Lactose & + & + & + & + & - \\
\hline Melibiose & + & + & + & + & - \\
\hline
\end{tabular}

(GE healthcare). The 16S rRNA gene (1488 bp) was amplified by PCR with the primers $8 \mathrm{~F}$ (Hallbeck et al., 1993) and 1492R (Lane, 1991). PCR products were cloned into the vector pCR2.1 using a TOPO-TA cloning kit (Invitrogen) and plasmid DNA was prepared by a Plasmid Miniprep kit I.E.Z.N.A. (Omega Bio-tech). Phylogenetic analysis was done according to previously described methods (Takeda et al., 2002). Strain HAQ-1 ${ }^{T}$ could be placed into the cluster of the genus Prosthecobacter (Fig. 2), indicating that the strain is a member of this genus. The closest relative of strain HAQ- $1^{\mathrm{T}}$ was the type strain of $P$. vanneervenii. Sequence similarity values with the type strains of the genus Prosthecobacter ranged from 93.1\% (Prosthecobacter debontii) to $97.1 \%$ (P. vanneervenii).

The G $+\mathrm{C}$ content of the DNA of strain $\mathrm{HAQ}-1^{\mathrm{T}}$ was estimated to be $62.9 \mathrm{~mol} \%$ by the HPLC method (Takeda et

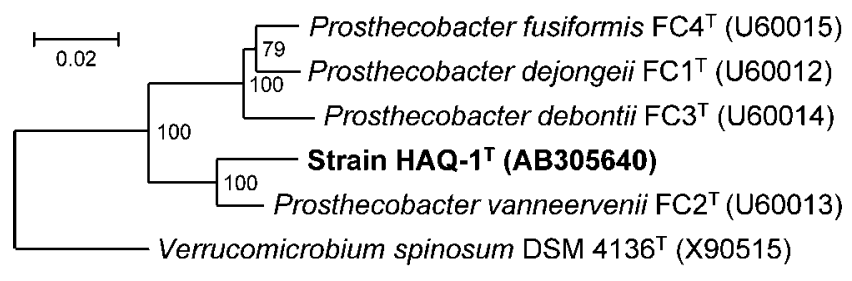

Fig. 2. Phylogenetic position of strain $\mathrm{HAQ}-1^{\top}$ among the species of the genus Prosthecobacter. The tree was constructed from an evolutionary distance matrix based on the neighbour-joining method (Saitou \& Nei, 1987). Bootstrap probabilities (percentages of 1000 replications) are indicated at branch points. Accession numbers are shown in parentheses. The sequence of Verrucomicrobium spinosum DSM $4136^{\top}$ was used to root the tree. Bar, 0.02 changes per nucleotide position. al., 2002). This value is slightly higher than the range (54$61 \mathrm{~mol} \%$ ) determined for other members of the genus Prosthecobacter (Staley et al., 1976) and the family Verrucomicrobiaceae (Hedlund et al., 1997). Both ubiquinone and menaquinone were detected by TLC according to a previously described method (Takeda et al., 2004). The spot of ubiquinone on the TLC plate was faint. Menaquinone was recovered from the plate and was further purified by HPLC under the following conditions: column, COSMOSIL $5 \mathrm{C}_{18}$-MS-II $(4.6 \times 150 \mathrm{~mm}$; Nacalai Tesque); temperature, ambient; eluent, methanol/isopropyl ether ( $75: 25)$; flow rate, $1 \mathrm{ml} \min ^{-1}$; detection, $A_{270}$. The predominant menaquinone was MK-6 $\left(\mathrm{H}_{2}\right)$, based on its retention time. Prosthecobacter strains are reported to contain both ubiquinone (not identified) and menaquinone [MK-6 $\left.\left(\mathrm{H}_{2}\right)\right]$ as major quinones (Hedlund et al., 1996; Staley et al., 1976), supporting the assumption that strain $\mathrm{HAQ}-\mathrm{1}^{\mathrm{T}}$ should be classified into the genus Prosthecobacter. Except for the G $+\mathrm{C}$ content, the major chemotaxonomic properties of strain HAQ- $1^{\mathrm{T}}$ were similar to those of the genus Prosthecobacter (Staley et al., 1976). In addition, the cellular fatty acids were identified by GC-MS according to previously described methods (Takeda et al., 2004). The major cellular fatty acids of strain HAQ- $1^{\mathrm{T}}$ were $\mathrm{C}_{14: 0}(42.0 \%), \mathrm{C}_{16: 1}(17.7 \%)$, anteiso- $\mathrm{C}_{15: 0}(9.7 \%)$, and iso- $\mathrm{C}_{14: 0}(5.7 \%)$.

The genes $b t u b A$ and $b t u b B$, which share high sequence identity with eukaryotic $\alpha$ - and $\beta$-tubulin genes, have been found previously in the genus Prosthecobacter and their expression has been confirmed in Prosthecobacter dejongeii (Jenkins et al., 2002). These genes are assumed to have been transferred from a eukaryotic cell by horizontal gene transfer (Schlieper et al., 2005). BtubA and BtubB potentially form filaments in a similar arrangement to $\alpha \beta$-tubulin (Schlieper et al., 2005; Sontag et al., 2005), and there is the possibility that these proteins contribute to the maintenance of the prothecate cell shape of Prosthecobacter strains (Sontag et al., 2005). However, the roles of these genes in Prosthecobacter strains have not yet been confirmed (Pilhofer et al., 2007). To elucidate whether strain HAQ $-1^{\mathrm{T}}$ has $b t u b A$ and $b t u b B$, PCR amplification of these genes was attempted using the primers and temperature program reported by Jenkins et al. (2002). Despite repeated trials, no products were obtained. For confirmation, other PCR primer sets (BTUBA-SF/BTUBASR for $b t u b A$; BTUBB-SF/BTUBB-SR for $b t u b B$ ) specific for $b t u b A$ and $b t u b B$ were newly designed on the basis of nucleotide sequences available from GenBank (Supplementary Figs S2 and S3). P. vanneervenii ATCC $700199^{\mathrm{T}}$ was grown in MMB medium at $25{ }^{\circ} \mathrm{C}$ for 3 days and its genomic DNA was prepared as described above as a positive control for the PCR assay. The desired PCR products were amplified from DNA of $P$. vanneervenii ATCC $700199^{\mathrm{T}}$ (Fig. 3). In contrast, no products were obtained from DNA of strain HAQ- $1^{\mathrm{T}}$ (Fig. 3), indicating that strain HAQ- $1^{\mathrm{T}}$ does not harbour btubA and btubB. These genes have probably been lost in some species during their evolution and are not essential for growth of 


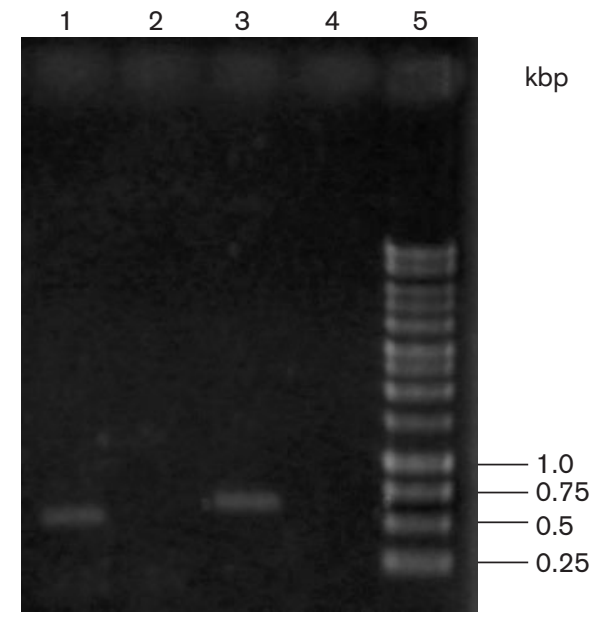

Fig. 3. Detection of the btubB (lanes 1 and 2) and btubA (lanes 3 and 4) genes by PCR. The PCR consisted of 30 cycles of $94{ }^{\circ} \mathrm{C}$ (30 s), $55{ }^{\circ} \mathrm{C}(30 \mathrm{~s})$ and $72{ }^{\circ} \mathrm{C}(30 \mathrm{~s})$, followed by extension at $72{ }^{\circ} \mathrm{C}$ for $7 \mathrm{~min}$. PCR products were separated on a $1 \%(\mathrm{w} / \mathrm{v})$ agarose gel. Lanes 1 and 3 were loaded with products from DNA of $P$. vanneervenii ATCC $700199^{\top}$, while lanes 2 and 4 were loaded with DNA of strain $\mathrm{HAQ}-1^{\top}$. Lane $5,1 \mathrm{~kb}$ DNA ladder (Promega).

Prosthecobacter strains. Since other Prosthecobacter strains have $b t u b A$ and $b t u b B$, the absence of these genes is a significant feature of strain $\mathrm{HAQ}-1^{\mathrm{T}}$. The genetic and phenotypic features of strain $\mathrm{HAQ}-1^{\mathrm{T}}$ suggest that it represents a novel species of the genus Prosthecobacter. The name Prosthecobacter fluviatilis sp. nov. is now proposed. In order to include strain HAQ- $1^{\mathrm{T}}$ in the genus Prosthecobacter, we also propose emended descriptions of the genus Prosthecobacter and the family Verrucomicrobiaceae.

\section{Emended description of the family Verrucomicrobiaceae Ward-Rainey et al. 1996}

The formal description remains as given by Hedlund et al. (1997) with the following modification. The G + C content of the DNA ranges from 54 to $63 \mathrm{~mol} \%$.

\section{Emended description of the genus Prosthecobacter (ex Staley et al. 1976) Staley et al. 1980}

The formal description remains as given by Staley et al. (1976) with the following modification. The $\mathrm{G}+\mathrm{C}$ content of the DNA ranges from 54 to $63 \mathrm{~mol} \%$.

\section{Description of Prosthecobacter fluviatilis sp. nov.}

Prosthecobacter fluviatilis (flu.vi.a.til'is. L. masc. adj. fluviatilis of or belonging to a river).

Cells are fusiform $(0.3-0.7 \times 1.8-8 \mu \mathrm{m})$ and straight. Growth occurs under aerobic conditions. Cells grown on
MMB medium occasionally form clumps. Colonies on MMB agar are pale yellow, convex and opaque. Growth occurs in the temperature range $10-38{ }^{\circ} \mathrm{C}$, with optimum growth at $30{ }^{\circ} \mathrm{C}$. Optimum growth occurs at $\mathrm{pH}$ 6.5-7.0. Ammonium salts are utilized as a nitrogen source. Vitamins are not required. The following carbon sources are utilized: D-glucose, D-galactose, D-mannose, sucrose, maltose, Dxylose, cellobiose, D-ribose, $\mathrm{N}$-acetyl-D-glucosamine and $\mathrm{N}$ acetyl-D-galactosamine. The following carbon sources are not utilized: lactose, melibiose, L-rhamnose, trehalose, Larabinose, D-fructose, raffinose, glycogen, D-glucosamine, Dgalactosamine and galacturonic acid. The $\mathrm{G}+\mathrm{C}$ content of the DNA of the type strain is $62.9 \mathrm{~mol} \%$. The type strain does not appear to possess the bacterial tubulin genes $b t u b A$ and $b t u b B$ based on PCR data.

The type strain is HAQ- $1^{\mathrm{T}}\left(=\mathrm{JCM} 14805^{\mathrm{T}}=\mathrm{KACC} 12649^{\mathrm{T}}\right.$ $=$ KCTC $22182^{\mathrm{T}}$ ), isolated from river water.

\section{References}

Eikelboom, D. H. (1975). Filamentous organisms observed in activated sludge. Water Res 9, 365-388.

Emerson, D. \& Ghiorse, W. C. (1993). Role of disulfide bonds in maintaining the structural integrity of the sheath of Leptothrix discophora SP-6. J Bacteriol 175, 7819-7827.

Ghiorse, W. C. \& Ehrlich, H. L. (1992). Microbial biomineralization of iron and manganese. In Biomineralization Processes, pp. 75-99. Edited by H. C. W. Skinner \& R. W. Fitzpatrick. Cremlingen-Destedt, Germany: Catena Verlag.

Hallbeck, L., Ståhl, F. \& Pedersen, K. (1993). Phylogeny and phenotypic characterization of the stalk-forming and iron-oxidizing bacterium Gallionella ferruginea. J Gen Microbiol 139, 1531-1535.

Hedlund, B. P., Gosink, J. J. \& Staley, J. T. (1996). Phylogeny of Prosthecobacter, the fusiform caulobacters: members of a recently discovered division of the Bacteria. Int J Syst Bacteriol 46, 960-966.

Hedlund, B. P., Gosink, J. J. \& Staley, J. T. (1997). Verrucomicrobia div. nov., a new division of the bacteria containing three new species of Prosthecobacter. Antonie van Leeuwenhoek 72, 29-38.

Jenkins, C., Samudrala, R., Anderson, I., Hedlund, B. P., Petroni, G., Michailova, N., Pinel, N., Overbeek, R., Rosati, G. \& Staley, J. T. (2002). Genes for the cytoskeletal protein tubulin in the bacterial genus Prosthecobacter. Proc Natl Acad Sci U S A 99, 17049-17054.

Lane, D. J. (1991). 16S/23S rRNA sequencing. In Nucleic Acid Techniques in Bacterial Systematics, pp. 115-175. Edited by E. Stackebrandt \& M. Goodfellow. Chichester: Wiley.

Makita, H., Nakahara, Y., Fukui, H., Miyanoiri, Y., Katahira, M., Seki, H., Takeda, M. \& Koizumi, J. (2006). Identification of 2(cysteinyl)amido-2-deoxy-D-galacturonic acid residue from the sheath of Leptothrix cholodnii. Biosci Biotechnol Biochem 70, 12651268.

Pilhofer, M., Rosati, G., Ludwig, W., Schleifer, K. H. \& Petroni, G. (2007). Coexistence of tubulins and fts $Z$ in different Prosthecobacter species. Mol Biol Evol 24, 1439-1442.

Saitou, N. \& Nei, M. (1987). The neighbor-joining method: a new method for reconstructing phylogenetic trees. Mol Biol Evol 4, 406425.

Schlieper, D., Oliva, M. A., Andreu, J. M. \& Löwe, J. (2005). Structure of bacterial tubulin BtubA/B: evidence for horizontal gene transfer. Proc Natl Acad Sci U S A 102, 9170-9175. 
Sontag, C. A., Staley, J. T. \& Erickson, H. P. (2005). In vitro assembly and GTP hydrolysis by bacterial tubulins BtubA and BtubB. J Cell Biol 169, 233-238.

Staley, J. T. \& Mandel, M. (1973). Deoxyribonucleic acid base composition of Prosthecomicrobium and Ancalomicrobium strains. Int J Syst Bacteriol 23, 271-273.

Staley, J. T., de Bont, J. A. M. \& de Jonge, K. (1976). Prosthecobacter fusiformis nov. gen. et sp., the fusiform caulobacter. Antonie van Leeuwenhoek 42, 333-342.

Takeda, M., Nakano, F., Nagase, T., lohara, K. \& Koizumi, J. (1998). Isolation and chemical composition of the sheath of Sphaerotilus natans. Biosci Biotechnol Biochem 62, 1138-1143.

Takeda, M., Kamagata, Y., Shinmaru, S., Nishiyama, T. \& Koizumi, J. (2002). Paenibacillus koleovorans sp. nov., able to grow on the sheath of Sphaerotilus natans. Int J Syst Evol Microbiol 52, 1597-1601.
Takeda, M., Nakamori, T., Hatta, M., Yamada, H. \& Koizumi, J. (2003). Structure of the polysaccharide isolated from the sheath of Sphaerotilus natans. Int J Biol Macromol 33, 245-250.

Takeda, M., Suzuki, I. \& Koizumi, J. (2004). Balneomonas flocculans gen. nov., sp. nov., a new cellulose-producing member of the alpha-2 subclass of Proteobacteria. Syst Appl Microbiol 27, 139-145.

Takeda, M., Makita, H., Ohno, K., Nakahara, Y. \& Koizumi, J. (2005). Structural analysis of the sheath of a sheathed bacterium, Leptothrix cholodnii. Int J Biol Macromol 37, 92-98.

van Ert, M. \& Staley, J. T. (1971). Gas-vacuolated strains of Microcyclus aquaticus. J Bacteriol 108, 236-240.

van Veen, W. L., Mulder, E. G. \& Deinema, M. H. (1978). The Sphaerotilus-Leptothrix group of bacteria. Microbiol Rev 42, 329-356. 